\title{
Universiteit
}

Leiden

The Netherlands

\section{Fire without smoke and other phantoms of Ambon's violence: Media effects, agency, and the work of the imagination}

Spyer, P.E.

\section{Citation}

Spyer, P. E. (2002). Fire without smoke and other phantoms of Ambon's violence: Media effects, agency, and the work of the imagination. Leiden: Universiteit Leiden. Retrieved from https://hdl.handle.net/1887/5373

Version: $\quad$ Not Applicable (or Unknown)

License: Leiden University Non-exclusive license

Downloaded from: https://hdl.handle.net/1887/5373

Note: To cite this publication please use the final published version (if applicable). 
Fire Without Smoke and Other Phantoms of Ambon's Violence:

Media Effects, Agency, and the Work of Imagination

Rede uitgesproken door

\section{Patricia Spyer}

bij de aanvaarding van het ambt van hoogleraar

in de Culturele Antropologie en Sociologie

van het huidige Indonesië

aan de Universiteit Leiden

op vrijdag 29 november 2002 
Mijnheer de Rector Magnificus,

Zeer gewaardeerde toehoorders,

My topic today is especially elusive and tangential. It concerns the role of the anticipated, the barely sensed, the possible, and the conditional in the structuring of ordinary peoples' perceptions and actions in extraordinary times of acute duress, crisis, and chronic violence. ${ }^{1}$ I aim to trace in the workings of the conflict in Ambon, with occasional forays into neighboring Moluccan Islands, the influence and effects of what is most often glossed by terms denoting a certain presence but bereft of any real precision such as "climate," "ambiance," "atmospherics," and "milieu." Elusive as this may sound, I hope to show that what I pursue here is not only crucial to making sense of Ambon and the war's unfolding over the past few years but that it also speaks to such anthropological staples as agency, the production of identity, meaning-making, and representation - though not in relation to the "normal" conditions with respect to which these are primarily thought but as refigured in the most extreme, even exceptional, of circumstances.

Since the outbreak of communal violence in Ambon city-the capital of the island of the same name in the province of Maluku—in mid-January 1999 up through the Malino II Peace Agreement of last February, much has been written about this conflict which over time consolidated two polarized religiosities-one Christian and one Muslim—as the war's main obvious opponents. These writers include anthropologists and other social scientists, both within and outside of Indonesia, activists and representatives of a range of local, national, and international NGOs, a number of protagonists within the conflict, as well as media practitioners based in Ambon and the surrounding islands, the capital Jakarta, or beyond the country's borders especially in Australia, the Netherlands, and the USA. ${ }^{2}$

In reports ranging from highly engaged and informed analyses to the more codified versions of NGO-speak, and the "contaminated" slanted stories that bolster the truth claims of one or another side, the origins, complicating factors and backgrounds, major events, and relevant national and international developments have been scrutinized and amply discussed in terms of their respective contributions to Ambon's violence. Acting as so many theatrical backdrops against which the main action unfolds, important externalities and internal factors have been named as enabling and providing fertile ground for the outbreak of violence; these include such macro political and economic structures as the Southeast Asian financial crisis of 1997 and its aftermath, the stepdown of Suharto and the transitions of Reformasi, and the behind-the-scene connivings of Jakarta's political elite and the military. Tensions among Ambonese Christians and Muslims, more specifically, are seen as having been aggravated over the long term, as well as more recently, by the religious division of labor established under Dutch colonial rule which privileged Christians and marginalized Muslims socially, economically, and educationally; the parallel processes of Islamicization and Christianization in the wake of World War II and the 
related erosion of the common ground of "custom" or adat shared by Ambonese;"; and the "greening" or Islamicization of Indonesia generally under the late Suharto regime as evidenced in Ambon by the appointment of two Ambonese Muslims as provincial governor, a development that left Christians feeling they were now the ones being left behind. ${ }^{4}$ Add to this increasing land shortage, population pressure, and the in-migration of Muslims from South Sulawesi, ${ }^{5}$ which skewed the more or less equal numerical balance on the island between Christians and Muslims, and the involvement of some Ambonese (especially urban youth) in gangs and criminality and one has a situation waiting to happen. Waiting to happen perhaps, but still not yet, not quite, happening.

I have learned from and generally subscribe to many of these arguments and analyses that I have summarily reviewed here. But I have also been troubled by the sense that something is missing. Some of this writing is just too grand, too abstract, and too removed from the volatile fractured field where Ambonese men, women, and children piece together their everyday lives out of the fears, contingencies, insecurities, and apprehensions that now weigh upon them. What tends to be passed over in foregrounding the influence of Indonesia's major political players-the networks of militant Muslims, the nefarious wheelings and dealings of thugs, the inbred violence, corruption, and partisan affections of the police and the military, and the shadowy plots of provocators and puppeteers-is the character of the very space in which all of these figures, for better or for worse, deploy their schemes and make their dubious marks.

Too little heed is given to the work of the imagination and the construction of knowledge in all of this and, specifically, to how these compel and propel particular actions and shape those who carry them out. The mobile, dense, and murky terrain in which something that is waiting to happen does, in fact, happen is built on spirals of information, misinformation, and disinformation, on the revamping of criteria of credibility, customs of trust and accountability, and on knowledge forms that blur the boundaries between what is seen and what is heard, what is known and what is suspected, what is feared and what is fantasized, what is fact and what is fiction. ${ }^{\text {? }}$ This, I believe, is what is meant by "climate." No mere backdrop, climate's infrastructure in Ambon comprises the overt and covert representations and mobilizations of both mass and more small-scale, politically driven "tactical" media, the circulation and sedimentation of ideologically potent images and hard-edged reified positions, as well as rumors, graffiti, unknowables, and even unnamables. These haunt the terrain in which big men, regular folk, and shadowy characters move and these structureequally but differently - their varied perceptions and actions. More blatantly than in other settings, agency in such circumstances also means being acted upon-suffering bodily exposure, terror, and enforced passivity. Before I turn to some examples, an outline of the conflict is in order.

On January 19, 1999 a run-of-the-mill fight between a Christian bus driver and a Muslim passenger escalated into a full-scale battle between Christian "red" 
forces and Muslim "white" forces fought out in the streets of Ambon with traditional or homemade weapons-knives, spears, machetes, arrows shot from slingshots, fishing bombs, and Molotov cocktails. By the end of the day, numerous houses, stores, offices, churches, and mosques had been destroyed or burned, scores of people had been displaced, and others wounded or killed. On the eve of the Malino II Peace Agreement, some three years later, the International Crisis Group estimates a minimum of five thousand and possibly as many as ten thousand people were killed and close to 700,000 refugees, equaling one-third of a total Moluccan population of 2.1 million, comprising also those fleeing violence on neighboring islands. ${ }^{8}$ In the largely residentially segregated city of Ambon, the kind of sectarian border skirmish that set all this off was common. Under normal circumstances it would also have remained a non-event-except, of course, for those immediately involved.

In what scholars increasingly identify as this first phase of the war, which lasted from mid-January 1999 until May 2000, periods of violent confrontation between native Ambonese Christian and Muslim mobs and mass destruction alternated with lulls, during which attempts at reconciliation involving elite Ambonese from both sides were occasionally made. ${ }^{9}$ Jakarta's blunders also begin early on, as the first troops sent to quell the violence were dispatched from South Sulawesi-that part of Indonesia from which the Muslim migrants driven out of Ambon during the conflict's first weeks also hail — with shoot-on-sight orders, and with a general lack of initiative and direction. This first phase is also marked by the outbreak of violence in the Kei Islands in Southeast Maluku in April 1999 and in the soon-to-be declared new province of North Maluku in August of the same year.

Phase two marked a qualitative change in the civil war, with the arrival to Ambon in May 2000 of the so-called Laskar Jihad. ${ }^{10}$ Called into existence out of a rising concern among Muslims that the Christians had the upperhand in the conflict, this militant Muslim organization with recruits from Java, Sumatra, and South Sulawesi, provides both partisan humanitarian assistance and armed support. The Laskar Jihad emerged in the wake of a massacre of four hundred Muslims in a mosque in North Maluku in late December 1999 and was further authorized by a more general call for jihad during a mass rally in Jakarta held in early January 2000 under the auspices of such major Indonesian political figures as the country's current vice-president, Hamzah Haz, and the People's Consultative Assembly Speaker (MPR, Majelis Permusyawaratan Rakyat), Amien Rais.

The amount and sophistication of weapons used in the war had grown over time, but the Laskar Jihad brought a surplus of professional arms to Ambon. It also introduced some order into the local Muslim militias who initially, at least, welcomed these supporters, and it enjoyed the clear backing of segments of the armed forces. The Christians found themselves significantly outnumbered and outgunned, with the numbers of casualties and amount of devastation increasing proportionately. By late June 2000 a state of civil emergency was declared in both Maluku and North Maluku provinces, and a special conjoined force of elite troops was dispatched to Ambon. If 
the declaration of the state of emergency greatly curtailed civil liberties - not the least of the press - and further enhanced the militarization of everyday life, it also gradually limited the number of large-scale confrontations.

This second phase of the conflict was further characterized by a deepening of the religious definition of the opposing parties and the crystallization of relevant extremist discourses - to wit, that of militant Islam and jihad, represented by the Laskar Jihad and the smaller, more covert Laskar Mujaheddin, on the one hand, and that of nostalgic sovereignty and separatism, on the other, promulgated by the Christian FKM (Front Kedaulatan Maluku, Front for Moluccan Sovereignty). Posing as the successor to the former RMS (Republic of the South Moluccas) movement, which in actuality only exists as a shadow of its former self among segments of the Moluccan population in the Netherlands, the FKM aims to bring about the nostalgic resurrection of an indigenous, "Alifuru" Moluccan identity, and boasts a leader who models himself after Xanana Gusmão, current charismatic leader of former East Timor, which recently achieved national sovereignty and so figures as a model.

With the decrease by 2001 of large-scale confrontations and their replacement by sporadic bombings and sniper attacks, the partial restraint of the Laskar Jihad under civil emergency conditions, and the signing of the Malino II Peace Agreement in early 2002, a third, still-ongoing phase of the conflict can be tentatively discerned. A declared state of civil emergency remains in effect, as does the concomitant militarization of daily life and the banning of foreigners from Maluku. The sense of euphoria in Ambon's streets following last February's Malino agreement has been marred by the intermittent explosions and attacks which many suspect are orchestrated by those who profit from the perpetuation of chronic, low-scale violence: segments of the military and police, individual deserters from the same, local gangsters, militant groups, and possibly more shadowy protagonists. ${ }^{11}$ The city remains divided into rigorously defended, religiously marked territories or, as one source acutely observes, "concentrated pools of resentment and bitterness,"-in other words, potential breeding grounds for more violence alongside — it must be said-emerging neutral zones and places of resistance and peace. ${ }^{12}$ This, in broad strokes, is the war. Much has obviously been left out of this summary — not the least the kinds of atmospherics to which I alluded earlier.

Let me begin at the beginning-itself a point of bitter contention between Christians and Muslims, since each side accuses the other of largely preparing and master-minding the onset of violence. As others have also pointed out, Ambon is not an island unto itself, which means that Christians and Muslims living there are cognizant of violence elsewhere, especially when it is religiously inflected. As on Lombok, an island some one thousand miles west of Ambon, where following an outbreak of anti-Christian riots in early 2000 graffiti on a house read "this is in response to what was done to Muslims in Ambon," ${ }^{13}$ so too, on Ambon, events in other places may seize hold of the imaginations of Ambonese. Most accounts of the war name a fight between Ambonese gangsters at a gambling den in Ketapang, Jakarta in November 
1998, the ensuing anti-Christian violence and church-burnings following the deaths of four Muslims, and the arrival of more than one hundred uprooted underworld preman to Ambon as events that precipitated trouble in January.

What is usually not mentioned is a meeting convened by the Governor in the intervening month of December. ${ }^{14}$ Meant as precautionary, the meeting instilled a sense of the possible in an already nervous city, working as an augury of what might happen before it actually occurred. The governor impressed upon Ambon's Muslim and Christian communities the need to be prepared, to be on the alert, on the lookout, and to guard against rumors. Both sides went home and set up posko, either communication or command posts-a slippage which suggests how easily the one slides into the other-with networks of mosques and churches connected by both cellular and regular phones.

In this case, being prepared for the worst can in crucial respects be said to have produced the worst. When on January 19 the fight broke out in the marketplace, each side quickly mobilized its members, staging in no time at all a battle between "reds" and "whites". Ironically to this day, it is precisely this preparedness and visible organization that each side holds out to the other as proof of their opponent's preconceived plan to mount an attack. It is also this which many scholars seize upon as evidence of large-scale, coordinated, behind-the-scene machinations.

My second example of how anticipation augurs what actually comes to pass also derives from that same first, fateful day, one which happened to coincide with Idul Fitri, the festive close of the Muslim fasting month, Ramadhan. In retrospect some may see January 19, 1999 as falling into the category of "likely violence days," a formulation coined by a US Embassy security officer in Israel in recognition of the patterned repetition of violent outbreaks on Palestinian commemorative occasions. ${ }^{15}$ Whether conjoining identity and trauma or, as with Idul Fitri, religious celebration and community, such days are charged with a practiced, ritualized sense of collectivity. Yet in many parts of Indonesia, and certainly Ambon, the celebration of Idul Fitri is also cross-cut, its alleged communalist potentiality complicated by inter-religious conviviality, hospitality, and sharing.

In this way, a journalist acquaintance of mine found himself on that first day at the office of Ambon's Suara Maluku newspaper, alternately taking calls from a Muslim friend at home in the neighborhood where the battle subsequently broke out - the two of them were making plans for the party that evening — and a Christian friend with whom he was coordinating their joint attendance at the feast. On call from different ends of the city, his ongoing double conversation with the two friends and colleagues was itself an instance of the first stirrings of the conflict. After they had set their plans, the Muslim friend immediately called back, telling my friend to bring his camera since a fight had broken out—a regular fight, he said, the kind of thing we have seen before. Then the other friend called again, too, saying he would not come since people were in the streets with machetes, up in arms because of a burned-down church. Caught in between, my friend heard of both mosques and 
churches burned before any smoke was signaled in the city. As he himself put it, the rumor preceded the event and, contrary to laws of nature, where there was fire no smoke had been seen. Indeed, the only fire around was a surplus of misinformation and suspicion circulating like wildfire with incredible speed across Ambon. ${ }^{16}$

A strictly chronological account would fail to do justice to the erratic rhythms and unfoldings of the war which ride as much on fantasy and desire as on apprehension and fear. Rather than try to extricate a causal chain, I argue that confounding any clear trajectory from which one might plot the actions of the various parties involved is a swirl of images, vocabularies, sound-bites, slogans, and vectors introducing a host of mediatized and mediated elsewheres into the picture-or, inversely projecting Ambon, with all its troubles and sufferings, onto a larger than local scale. It is in the thick of such things and their powerful effects that one may begin to address Ambon's violence. ${ }^{17}$

Take the difference between the Christian "reds" and the Muslim "whites". If I have given the impression thus far that these stood each other off from that first day as ready-made enemies, that impression is misleading, for in fact this was hardly the case. Contrary to easy discussions of "dehumanization"- as if involving something that people wake up to one day and decide to do-the distancing that "dehumanization" presumes must actually be produced, with an enemy made and identities recognized and reforged in the heat of impending and ongoing confrontation. Once enmity is sealed in bloodshed and memory and codified through collective talk and imagery, dehumanization can apparently—horrifically and amazingly—become second nature for just about anyone-over time. For all the underlying tensions, interreligious rivalry, dark legacies of the Suharto era, and even turf wars between the military and police, the civil war in Ambon has been just that: civil, largely fought out among Ambonese, that is, among former colleagues, friends, and neighbors. A refugee from the area even suggested that the color-coordinated headties worn from the beginning on both sides were imperative to telling each other apart—given, he said, that we are all Ambonese.

Perhaps such colors could not sufficiently conjure difference out of takenfor-granted sameness or bear the weight of growing fear and hatred as the experience of war with its trail of anger, loss, and grief increasingly shaped the terms of perception and action on either side. Perhaps hatred is precisely such a restless search for new names and new labels in which provisionally to shelter an emotion that inevitably exceeds them. Whatever the case, additional names and images of the enemy-Other accreted along the way, further deepening the divide between Muslims and Christians and making it more difficult to imagine its undoing. A by-now infamous PSA (Public Service Announcement) broadcast on national TV and several commercial channels some months after the violence began seems to have been compelling enough to emerge as an emblem of mutual enmity. Shortly after its airing, the spot took on a life of its own, one quite different from that intended by its producer, who, as a result, now claims to suffer "trauma." 
A sweet, sentimentalized vignette of only several minutes, "Voice of the Heart-Acang and Obet" features two young Ambonese boys, the Muslim "Acang," short for Hassan, and his bosom friend, the Christian Robert or "Obet." 18 The scene takes place in an abandoned, gutted-out basement of a large concrete building evoking the ravages and dislocations of war. The spot opens with Acang awaiting his friend, anticipation on his face, and shows the smiles and joy of both boys when Obet arrives. The two share a quick, stolen conversation in which the more obvious problems afflicting Ambon's children somewhat stiffly parade by: Obet complains we can't go to school, see our friends, study at home, or sleep, Acang that he misses school since living in a refugee camp where life is difficult. To Acang's question "why did Ambon fall apart like this?," Obet responds, "I don't know, its a problem of adults." Acang is left with the punchline: "its an adult problem and us kids are the victims." The camera zooms in on the two friends, who are posed with their arms around each other, speaking jointly from the heart, the one echoing the other, voicing the hope and mutual promise that "even if Ambon is destroyed like this, our bond of brotherhood should not be broken."

The spot has all the trappings of the documentary-sophisticated photorealist technique and a credible backdrop bolstering cinema's illusory realism, ${ }^{19}$ authentic Ambonese dialect, Indonesian subtitles, and two emblematic Ambonese young boys. The drama resurrects the trope of friends torn apart by uncontrollable circumstances-a dramatic situation seen on screen as early as D.W. Griffith's 1915 classic Birth of a Nation, set in America's Civil War, but also portrayed more recently, with the Indonesian Revolution as setting, in the film version of Hella Haasse's book, Oeroeg. Strikingly though, unlike their predecessors-whether standing in for North and South or the Netherlands and newborn Indonesia-"Voice of the Heart"s Ambonese heroes do not grow up.

To be sure, children are the future of any nation and emphatically so in Indonesia where some 70 percent of the population is under the age of twenty. The war in Ambon has had terrible effects on everyone, not the least children, many of whom have been left fatherless, orphaned, homeless, in refugee camps, and out of school. ${ }^{20}$ Many have seen and experienced horrific things and many, too, have participated in their making, serving as militia messengers on both sides, becoming skilled producers of crude, deadly weapons, torching houses and vandalizing neighborhoods after an attack. One source claims that between two thousand and four thousand children, aged seven to twelve—or the same as Acang and Obet—have taken part in raids on "enemy" villages or assisted in defending their own. On the Christian side they are known as pasukan agas,"sandfly troops," among the Muslims pasukan linggis. $^{21}$

What fantasy, in brief, structures "Acang and Obet?" Letters and poems of refugee children testify, indeed, to their longings for former playmates. ${ }^{22}$ In contrast to these other children, who have no space for a reunion, Acang and Obet are provided with a cave-like shelter that acts as a microcosm where, speaking from children's 
hearts, the pair evoke the pela blood-brotherhood mythologized in Maluku and currently refigured in peace and reconciliation dialogue. Their space is also a haven of apolitical innocence, located less beyond the upheavals of dislocation, refugee status, interrupted schooling, and everyday trouble — which the spot clearly names-but, more significantly, beyond the politics, power structures, and political-economy permeating and informing all of these. The diminutive child's world also serves to diminish the conflict, bringing it down to size, shrinking it to an instance of spokenfrom-the-heart childhood honesty and clairvoyance, and thereby trivializing its real impact on Ambonese children. Further, by blaming adults for Ambon's violence, the spot induces a double delegitimization —of the parents of all Obets and all Acangs and of pemuda or "youth," a morally charged category on the crest of all fundamental change in Indonesia thus far. What remains after this pernicious erasure is an abstract, easily appropriable clarity — a schematism amenable to all kinds of ends, including violence.

A name and face for the enemy is all that Ambonese took from the spot meant to foster peace among them. Interviews with refugees on my tapes from the last two years are replete with phrases like "Acang attacked," "Obet's territory," and so on, testifying to the currency of "Voice of the Heart"s unforeseen after-life. ${ }^{23}$ If, arriving unwittingly from elsewhere, Acang and Obet's message went awry in its adjustment to Ambon's conditions so, inversely, do Ambonese actively borrow examples from other places held to approximate their own fraught world. Well before September 11, although I cannot date its emergence, the city's main dividing line between its Muslim and Christian parts has been known colloquially as the "Gaza Strip," Jalur Gaza. This name was already prepared in the first days of the conflict, when graffiti desecrating walls and buildings included insults of Jesus and the Prophet Muhammad, references to Jews, Israel, Muslim Power and Muslim Pigs, stars of David, and the phrase "Allahu Akbar" in Arabic writing. ${ }^{24}$ Such fragmentary, freefloating bits of discourse work best in display mode- on T-shirts, banners, posters, headties, as visual and verbal slogans. Coming out of context, they also transcend it, becoming both monumental and indexing a universe, one of closed ideological systems and stand-off positions. ${ }^{25}$ Over time, the mirrored vocabularies and practices of Ambon's two intimate enemies, emergent out of their ongoing negative exchange, further sedimented the city's own Gaza Strip.

My interest in this usurpation of a powerful name from elsewhere is double: in terms of its effects within the dynamics of the conflict, which are both more than local and less than global, though feeding off of and beholden to much larger than national designs; and in terms of the mediatized, mediated realities of Ambon, as virtualized as almost anywhere these days, especially since the war. Akin to the "synchronic novelties" identified by Benedict Anderson with the beginnings of the imagination of community as nation—like New York, New London, Nueva Leon, Nieuw Amsterdam-Ambon's "Gaza Strip" could "arise historically only when substantial groups of people were in a position to think of themselves as living lives par- 
allel to those of other substantial groups of people-if never meeting yet certainly proceeding along the same trajectory."${ }^{26}$ Twinning these war-torn places may be one way of making the violence in Ambon-hardly a priority in Jakarta—matter, a way of lending local suffering and loss larger than local meaning. ${ }^{27}$ It also demonstrates the theatricality and dramatic imagining of social actors in a world dominated by NGOs, international peace-keeping initiatives, Human Rights Watchers, and other important audiences. ${ }^{28}$ One wonders, however, if the import of the conflict, once amplified, can thereafter so easily be scaled down ${ }^{29}$-adding an ironic twist to Marx's famous insight that men make their own history though not in conditions of their own making.

Such neat schema and ideologically compelling images, like those taken from "Voice of the Heart" and "Gaza Strip," are part of a much larger arena of conflicting messages, fragmentary information, representational immediacy, and stark clear-cut abstraction. They share the same space with phantom letters proven incendiary enough to trigger large-scale violence. One especially infamous incident involved a letter allegedly issued by Ambon's Protestant Church and calling for Maluku's Christianization which once multiplied, read aloud over megaphones, and spread about, led directly to the dislocation and deaths of numerous North Moluccans. ${ }^{30}$ Such "dark" circuits underlie, cross, and compete for attention with partisan descriptions disseminated by the local press (the aforementioned Suara Maluku newspaper, for instance, has spawned separate Muslim and Christian editions), with village gossip presented as truth on Christian and Muslim websites, and with Christian-inclined state radio vying with illegal Muslim radio stations (at one point the Laskar Jihad station dominated all the airwaves in Ambon, crowding out other channels, and even infiltrating the handy-talkies of priests). These divergent and convergent voices and views drown out, echo, interrupt, and jostle each other in the cramped, ideologized, divided space of Ambon, with all its mediated elsewheres, amplified, narrow-cast, obscure, and confusing realities.

Even the supposedly (on the face of it) simple problem of actors-the whodun-it of the violence-can be hard to pin down. Take the abstract lexicon produced by some, non-partisan, pro-peace press journalists-people with the very best of intentions. With the aim of diminishing the conflict, these reporters often deliberately obfuscate the information of a violent exchange. Reading their accounts, one is left none the wiser; in these reports the numbers of casualties and accounts of ruined property masquerade as precision alongside references to houses of worship stripped of denomination, and a string of elusive actors: "certain parties," unidentified "political elite," "puppeteers," and the ever-popular "provocator." ${ }^{31}$ Whatever its aim, this lack of specificity to agency may in fact produce a sense of phantom danger, which lurks both nowhere in particular and therefore potentially everywhere in general, provoking fear and, perhaps even, new violence..$^{32}$ Alongside, moreover, phrases like "Muslim cleansing," imported early on from Jakarta, and other vivid, slanted versions of war, a more neutral source is quickly marginalized since—as one Ambonese journalist put it—it appears ludicrous by contrast. 
At first glance, the Video CDS or VCDs, produced by both Christian and Muslim partisons but circulated only by the latter (for this reason I focus on the Muslim VCDs) fly in the face of these other stark, stripped-down media reports. The VCDs' emotional appeal depends upon their sympathetic, almost tactile engagement with victims and their bodies: on close-ups of oozing wounds, bullets protruding from body parts, maimed and charred corpses, and the bodily contortions, moans, and screams of people's suffering too painful to watch. But they are watched, over and over again. Besides pictures of victims, these VCDs also show the occasional imam or Muslim NGO spokesperson, and the disembodied hands of surgical intervention (doctors themselves are rarely shown), so that the main action generally consists of mass scenes of attack and violence drawn from the war's earlier phases. ${ }^{33}$ Very much in "the thick of things," these VCDs provide little perspective on events and often make no pretension to having a narrative, besides, that is, the insistent, repetitive narrative of victimization resurrected on and out of body parts.

These VCDs are composite works; they range from the more professional to the homemade, though both "grades" of CDs often contain the very same clips, which are clearly shared and copied widely. Whereas in numerous shops throughout Indonesia it is possible to compile CDs of one's favorite songs, in Ambon it is possible to select favorite scenes of violence to be compiled on a personal VCD. Some of the clips are produced, or at least endorsed by the military; these feature soldiers casually standing by or doing their thing, neither shying away from nor interrupting the camera. Others are said to have been filmed by doctor-volunteers who not only stitch wounds but lend their steady hands and surgical gazes to the close-up cinematic engagement of broken bodies. Many of these VCDs have clearly been pieced together, and many evidence the presence of different hands - some, indeed, steady, others shaky, and yet others apparently taken with the zoom function.

How does the mass appeal of the VCD genre translate into the actual creation of community and the shaping of perception and action in the conflict? This is a question with presumably somewhat different answers for Ambon's Muslim and Christian peoples, and one that I cannot pretend to really address here. If, however, community has anything to do with the circulation and consolidation of shared symbols, memories, and sentiments, then the nature of their mode of transfer and sedimentation is clearly important. Among Christians in Ambon, VCD traffic is relatively small-scale, difficult to break into, and closely controlled, with CDs bearing advisory labels like "intended for own group (untuk kalangan sendiri)." The Muslim VCDs, by contrast, are not only mass-produced, sold in the markets and streets of much of Indonesia, but transnationally popular and quite homogeneous: Ambon's VCDs look much like Kashmir's, Bosnia's, and those of Palestine shown in Malaysia and elsewhere. ${ }^{34}$

For any of these VCDs to have any effect-whether in the claustrophobic enclave of Ambon's Christian community or the transnational Muslim space stretched thinly, perhaps, across the geopolitical mozaic of different Islams — at least 
two things are needed, which I can only name here. The first are codified discourses like those of the Laskar Jihad or Christian FKM, mentioned earlier, which serve as rallying cries or even captions that orient and provide a framework for perception and action. Second, as Arjun Appadurai and Deborah Poole have suggested for other settings there must be, what Raymond Williams calls "social expressions in solution, as distinct from other semantic formations that have been precipitated and are evidently and more immediately available. ${ }^{\prime 35}$ Neither institutionalized or reflexively present, such "social expressions in solution"—or "modes of affect and feeling attendant on emergent social processes_-,"inhabit a patchy, dispersed terrain, constituting community only as a potential. Along with other factors and media, the highly mobile VCDs are themselves, of course, part and parcel of the making of this terrain.

One of the most professional VCDs in my possession called "North Maluku's Suffering" (Maluku Utara Berduka), graphically intimates the kind of fluid, contingent "expressions in solution" which must have prefigured the Muslim community congealed on screen. ${ }^{36}$ On screen, the gathering, including several women and children, is bent to the common task of jihad in North Maluku but, I believe, in another situation, this crowd would have been just as easily dispersed. Visibly at least, the community is an ad hoc collection of eclectic affinities: everyone is dressed more or less in white, but some appear orthodox and sober, while others are inscribed from head to waist with azimat (magical charms dating to the Crusades), others are in Saudi-style dress, others wrapped in Palestinian headscarves, still others Jihad-Yogya style. Several carry Southern Philippine Moro-shaped machetes, others bows and arrows or spears, some AK-47s, while a few even wield plastic guns, perhaps for their effect on unsupposing audiences.

Throughout this talk I have stressed the role of the possible and the conditional — of which social expressions in solution form a part—or what might be called anticipatory practice in the context of extraordinary, violent circumstances. It remains very briefly to be suggested what people caught in the midst do-with multiple influences and images impinging upon them. Once again, the general climate of fear, insecurity, and mental and physical exhaustion which Ambonese inhabit everyday is important to bear in mind. These are the conditions for what I call a hyperhermeneutics, ${ }^{37}$ which could be defined as a compulsive need to interpret and mine just about everything for hidden meaning, to see any trivial occurrence as a sign or omen of what might come. There is, relatedly, the drive to produce signs, signs for one's own community, for other social actors, for larger relevant audiences, and, not the least, for the enemy-other; headties, graffiti, and the like are signs. Lest this seem too cerebral, the crucial dimension filling out this constellation of anticipatory practice is extreme, pervasive distrust: things are so thoroughly scrutinized because their nature and appearance are suspected of concealing something else. ${ }^{38}$

The prevalent assumption that things are other than they seem is nowhere more evident than in the discourse of disguise and revelation following an attack and running through the more general talk around the conflict. A discourse of hidden 
depth, such talk revolves around the discoveries made when corpses are undressed, when the folds and pockets of garments are explored and turned inside-out, disclosing a truer identity underneath; thus, a jihad fighter might reportedly be found with an army uniform under his robe, or dates in a pocket are seen as indexing a devious connection to the Middle East, or, again, folded papers with talismans are held to reveal the presence of hidden designs, and so on ${ }^{39}$ More disturbingly even, just under the surface of your regular Ambonese face, more and more people claim to discern its "Christian" or "Muslim" contours. This attempt to see through everything can only emerge in a situation where people in fact see nothing at all. This predicament-of being trapped in events beyond one's grasp and comprehension, of seeing no way out, of immersion in the thick context of terrible things—comes through poignantly on my taped conversations with Moluccan refugees and in the voices and demeanor of Ambonese men and women speaking on news reports made before last February's Malino Peace Agreement.

Exceptional circumstances like those of Ambon's civil war expose the norm, underscoring how much context is always a sedimentation of the imaginary and the product of imagination's work. In this talk I have implicitly challenged the taken-forgranted, if hopelessly impoverished, anthropological notion of the "ethnographic context" - in dire need of refurbishing for our radically changing twenty-first century world. Inevitably, I have glossed over complexities, highlighting certain dynamics at the expense of others equally important. I have spoken of media effects, agency, the work of imagination, and violence-elsewhere-always a tricky business. In the best of anthropological traditions, the study of "elsewhere" was from the beginning meant to promote reflection at home, to produce critical thinking on one's own society. Today we are all too aware that such elsewheres-once romanticized anthropological havens-increasingly impinge upon us, that their troubles and violence are our troubles and violence, too.

Aan het einde van mijn rede gekomen, wil ik allereerst het College van Bestuur bedanken voor het vertrouwen dat het in mij gesteld heeft bij deze benoeming en meer in het algemeen voor de brede steun aan de bestudering van Modern Azië. Verder wil ik aan allen anderen die aan de totstandkoming van deze benoeming hebben bijgedragen eveneens mijn dank uitspreken. In het bijzonder dank ik mijn decaan, Stan Maes en het Bestuur van de Faculteit der Sociale Wetenschappen voor het in mij gestelde vertrouwen en voor de steun aan nieuwe initiatieven.

Mijn leermeesters aan de University of Chicago-Marshall Sahlins, Nancy Munn, Barney Cohn en wijlen Valerio Valeri-blijven een belangrijk en inspirerend voorbeeld van intellectuele creativiteit en wetenschappelijke rigueur.

Hooggeleerde Schefold, Beste Reimar, als mijn voorganger op deze leerstoel waardeer 
ik ten zeerste de wijze waarop je mij in het departement ontvangen en gesteund hebt. Ik dank je voor de openheid en hartelijkheid die jij toont en voor je goede adviezen over het voorzitterschap en ons gemeenschappelijk specialisme Indonesië.

Hooggeleerde Geschiere, Beste Peter, mijn waardevolle ex-collega proximus, ik heb veel aan je wijze raad, aan je intellectuele voorbeeld, en aan je vriendschap. Ik dank je voor dit alles.

Beste collega's van het departement CA/SNWS mijn dank aan jullie allen die mij hebben bijgestaan sinds mijn komst naar Leiden en bij mijn eerste jaar als voorzitter. Naast alle andere collega's dank ik in het bijzonder Patricio, Wasif, Jarich, Jan en Peter Nas met wie ik de laatste tijd uiterst nauw en altijd plezierig heb samengewerkt. Ik heb veel aan jullie steun gehad en dat heb ik nog steeds.

Oud Collega's van de Onderzoeksgroep Godsdienst en Maatschappij aan de Universiteit van Amsterdam, het is sowieso aan jou Peter van der Veer en aan de onderzoeksgroep te danken dat ik in 1993 besloten heb vanuit de Verenigde Staten terug te keren naar Nederland. Ik waardeer jullie collegialiteit en vriendschap.

Collega's van de KNAW project Indonesian Mediations-Ben Arps, P.M. Laksono, Henk Schulte Nordholt, en de anderen-onze samenwerking is stimulerend en een groot plezier. Ik kijk uit naar de vruchten van ons gezamenlijk project en naar verdere contacten met de collega's van de opleiding Talen en Culturen van Zuidoost Azië en Oceanië.

Dames en Heren Studenten,

Veel van mijn dagelijks leven in Leiden heeft met jullie te maken en is aan jullie te danken. Ik beloof mijn uiterste te doen om in deze tijden van tekorten en bezuinigingen een zo goed mogelijk onderwijs en onderzoeksprogramma voor jullie te garanderen.

Old friends and colleagues, new colleagues and friends,--Ruth, Webb, Mary, Inge, Carel, Hent, Paola, Annelies, Birgit, Rikki, Axel, Wim and Victor it means a great deal to have all of you here today.

My parents, Helen and Dick Spyer, you have both taught and given me many things, thank you for your love and for your support.

Rafael my formidably intelligent and tender husband, thank you for everything.

Ik heb gezegd. 
1 The research on which this lecture is based is ongoing within the context of the "Indonesia in Transition" Program funded by the Dutch Academy of Sciences. I would like to thank the Dutch Academy of Sciences for its support of this fouryear research program as well as the members of the "Indonesian Mediations" subproject within this larger program for their continual stimulation. Rafael Sánchez provided inspiring commentary and suggestions for which I thank him gratefully. I am also indebted to the many Moluccan refugees who told me their stories, and to the media practitioners, NGO activists, members of religious and humanitarian organizations, and the many other ordinary Indonesians on whose comments and contributions this lecture draws.

2 A selection of the many publications includes, among the more academic, George Junus Aditjondro, "Guns, Pamphlets and Handie-Talkies: How the military exploited local ethno-religious tensions in Maluku to preserve their political and economic privileges," in Violence in Indonesia, ed. Ingrid Wessel and Georgia Wimhöfer (Hamburg: Abera Verlag, 2001), pp.100-128; Dieter Bartels, "Your God is No Longer Mine," apakabar(at)saltmine.radix.net, September 9, 2000; Nils Bubandt, "Malukan Apocalypse: Themes in the dynamics of violence in eastern Indonesia," in Violence in Indonesia, pp.228-253; Andries Greiner, ed., De Molukken in Crisis: Machteloos, ver weg, maar niet wanhopig, Actuele Onderwerpen 2691, February 18, 2000; Gerry van Klinken, “The Maluku Wars: Bringing Society Back In,” Indonesia 71 (April 2001): 1-26; Wim Manuhutu et al., Maluku Manis, Maluku Menangis: De Molukken in Crisis. Een poging tot verklaring van de geweldsexplosie op de Molukken (Utrecht: Moluks Historisch Museum/Moluccan Information and Documentation Center, 2000); Fridus Steijlen, "Kerusuhan Het misverstand over de Molukse onrust," pamphlet, Forum: Utrecht 2000; Tim Pengkajian Universitas Pattimura, "Analisis Sosial tentang Peristiwa Kerusuhan Berdarah di Kotamadya Ambon dan Sekitarnya Januari-Februari 1999," pamphlet (Ambon: np, 1999). NGO and activist works include "Indonesia: Overcoming Murder and Chaos in Maluku," International Crisis Group Report No. 10, Jakarta/Brussels, December 19, 2000; “Indonesia: The Search for Peace in Maluku," International Crisis Group (ICG) Asia Report No. 31, Jakarta/Brussels, February 2002; "Indonesia: The Violence in Ambon," Human Rights Watch Report, March 1999; Zairin Salempessy and Thamrin Husain, eds. Ketika Semerbak Cengkih Tergusur Asap Mesiu: Tragedi Kemanusiaan Maluku di Balik Konspirasi Militer, Kapitalis Birokrat, dan Kepentingan Elit Politik (Jakarta: Sekretariat Tapak Ambon, 2001); S. Sinansari ecip, Menyulut Ambon: Kronologi Merambatnya Berbagai Kerusuhan Lintas Wilayah di Indonesia (Bandung: Mizan, 1999); Luka Maluku: Militer Terlibat (Jakarta: Institut Studi Arus Informasi [ISAI], 2000); Tim Penyusun al-Mukmin, Tragedi Ambon (Jakarta: Yayasan Al-Mukmin, 1999). Other sources (including some by protagonists in the conflict) are Erwin H. Al-Jakartaty, 
Tragedi Bumi Seribu Pulau: Mengkritisi Kebijakan Pemerintah dan Solusi Penyelesaian Konflik (Jakarta: BukKMaNs, 2000); M Husni Puruhena, SH, Buku Putih-Tragedi Kemanusiaan dalam Kerusuhan di Maluku. Sebuah Prosesi Ulang Sejarah Masa Lalu (Ambon: np, 1999); Rustam Kastor, Konspirasi Politik RMS dan Kristen Menghancurkan Ummat Islam di Ambon-Maluku (Yogyakarta: Wihdah Press, 2000); Rustam Kastor, Suara Maluku Menbantah/Rustam Kastor Menjawab (Yogyakarta: Wihdah Press, 2000); Mediator Dalam Kerusuhan Maluku (Jakarta: Sekretariat Komisi Kateketik KWI, 2001); Tragedi Kemanusiaan Maluku dipersembahkan kepada dunia internasional atas nama rakyat Maluku yang menderita oleh Front Kedaulatan Maluku (Ambon: np, 2000); Jan Nanere, ed., Halmahera Berdarah (Ambon: Bimspela, 2000).

3 For a good history of Ambonese society from the Dutch colonial rule of the latenineteenth century through the nationalist movement, independence, and the Republic of the South Moluccas (RMS) movement of the 1950s, see Richard Chauvel, Nationalists, Soldiers and Separatists (Leiden: KITLV Press, 1990). Juliet Patricia Lee provides a more recent assessment of Ambonese society, its transformations under the Suharto regime, and Muslim-Christian relations in her doctoral dissertation "Out of Order: The Politics of Modernity in Indonesia" (PhD dissertation, Department of Anthropology, University of Virginia, 1999). On the widely publicized pela or blood-brother relations which conjoin some Muslim and Christian villages and kin groups, see Dieter Bartels, "Guarding the Sacred Mountain: Intervillage Alliances, Religious Syncretism and Ethnic Identity among Ambonese Christians and Moslems in the Moluccas" ( $\mathrm{PhD}$ dissertation, Department of Anthropology, Cornell University, 1977), and his "Your God is No Longer Mine." Richard Chauvel offers an excellent critical evaluation of the deployment of pela for political purposes, in addition to information on Ambon's Muslims in his "Ambon's Other Half: Some Preliminary Observations on Ambonese Moslem Society and History," Review of Indonesian and Malaysian Affairs 14,1(1980): 40-80.

4 On the Islamicization of Indonesia under the late New Order, see Robert W. Hefner, Civil Islam: Muslims and Democratization in Indonesia (Princeton: Princeton University Press, 2000), and "Islamization and Democratization in Indonesia," in Islam in an Era of Nation-States: Politics and Religious Renewal in Muslim Southeast Asia, ed. Robert W. Hefner and Patricia Horvawitch (Honolulu: University of Hawai'i Press 1997), pp.75-127.

5 At issue here is recent migration dating from the 1970s. More generally, Ambon has attracted migrants already for several centuries-including peoples from South Sulawesi. See Gerrit J. Knaap, “A City of Migrants,” Indonesia 51 (April 1991): 105-132.

6 For an insightful discussion and history of the category of "youth," see Jean and John Comaroff, "Reflections on Youth, From the Past to the Postcolony," in Youth 
in Africa: Producing Futures in a Global Age, ed. Ron Kassimir, Jean Comaroff and John Comaroff (New York: under the aegis of the Social Science Research Council, forthcoming).

7 See Ann Laura Stoler's excellent “'In Cold Blood': Hierarchies of Credibility and the Politics of Colonial Narratives," Representations (Special Issue: Imperial Fantasies and Postcolonial Histories) 37 (1992): 151-189. Her reading of the colonial sources that were part of "the gossamered climates of violence" within which stories of a planter's murder were told proved useful to me in thinking about Ambon's violence. Some of the differences between evaluating such murky events through written, colonial documentation and, by contrast, through my own approach (based, among other things, on conversations and interviews with refugees and media practitioners) are instructive. Arjun Appadurai's helpful "Life After Primordialism" also addresses some of the issues discussed here. See Arjun Appadurai, Modernity at Large: Cultural Dimensions of Globalization (Minneapolis: University of Minnesota Press, 1996), pp.139-157.

8 ICG Asia Report No.31, "Indonesia: The Search for Peace in Maluku," Jakarta/Brussels, February 8, 2002.

9 See Bartels, "Your God in No Longer Mine," and Aditjondro's “Guns, Pamphlets, and Handie-Talkies."

10 Kirsten E. Schulze provides one of the most informative discussions of the Laskar Jihad's background as an organization and of its activities. See Kirsten E. Schulze, "Laskar Jihad and the Conflict in Ambon" in The Brown Journal of World Affairs IX,1: 57-69, 2002. For a more general discussion see "Indonesia: Violence and Radical Muslims,” Indonesia Briefing, International Crisis Group, Jakarta/Brussels, October 10, 2001.

11 On the problem of Ambon's "rebel soldiers" or deserters, see "Perang Tentara Pembangkang di Ambon,” Tempo, edisi 10, June 16, 2002, pp.24-37.

12 ICG Asia Report no.31, p.17.

13 Leena Avonius, unpublished $\mathrm{PhD}$ dissertation, in progress.

14 See, however, "Indonesia: The Violence in Ambon," Human Rights Watch Report, March 2000, p.6; and "Island of Ambon is Worst Trouble Spot in Indonesia," Radio Australia Indonesia Service, interview with Moluccas specialist Richard Chauvel, Ambonese journalist Rudi Fofid, and Sidney Jones, Asian Director of Human Rights Watch, broadcast on March 5, 1999. My thanks to Rudi Fofid for a transcription of this broadcast.

15 Lori Blumenfeld, Revenge: A Story of Hope (New York: Simon \& Schuster, 2002), p.54, with thanks to Michael Fischer for bringing this book to my attention.

16 Any kind of balanced information was, not surprisingly, one of the first victims of 
the violence. Soon after the conflict broke out, the friends and Suara Maluku colleagues mentioned here could no longer come together, as their office was located in the now-Christian part of the city and their printing press across the border in Muslim territory. Seizing a good business opportunity when it emerged, the Jawa Pos - the Surabaya-based owner of Suara Maluku—created a Muslim-spin-off, Ambon Expres, from the Suara Maluku, which under the circumstances increasingly defined itself as a Christian mouthpiece and community paper. For a general discussion of the press in Indonesia-including Jawa Pos' business strategy, see Krishna Sen and David T. Hill, Media, Culture and Politics in Indonesia (Oxford: Oxford University Press, 2000). See Tim Allen and Jean Seaton, eds., The Media in Conflict: War Reporting and Representations of Ethnic Violence (London: Zed Books, 1999) on the role of especially the mass media in situations of war. See also Philip Kitley's astute comments on media practice in conflicted situations in "Into the Thick of Things: Tracking the Vectors of 'Indonesian Mediations.' A Comment," in Indonesia in Search of Transition, ed. Henk Schulte Nordholt and Irwan Abdullah (Yogyakarta: Pustaka Pelajar, 2002), especially pp.212-214.

17 With warm thanks to Philip Kitley for suggesting vectors as one way of tracking media effects in a confusing and changeable terrain and for advocating immersion in "the thick of things." See Kitley "Into the Thick of Things ..."

18 I would like to thank Victor Joseph and Wim Manuhutu for helping me procure the Public Service Announcement. Produced by Franky Sahilatua.

19 On the workings of backdrops, see Robert J. Gordon, "Backdrops and Bushmen: An Expeditious Comment," in The Colonising Camera: Photographs in the Making of Namibian History, ed. Wolfram Hartmann, Jeremy Silvester, and Patricia Hayes (Ohio University Press, 1998), pp.111-117.

20 See also George Aditjondro, “Guns, Pamphlets and Handie-Talkies,” p.101.

21 From the refugees I interviewed in Manado I only heard the term pasukan agas. Other scholars of Maluku whom I questioned about the meaning of pasukan linggis offered different explanations of the word linggis. Wim Manuhutu claims linggis is a kind of fruit. James T. Collins offered a more historical interpretation. According to him, in Indonesian linggis means "crowbar." During the Japanese era there was a song (said, incidentally, to have been written by an Ambonese) the chorus of which was as follows:

Itu Inggris, kita linggis

Amerika kita seterika

Translation: “The English we'll just crowbar [prise] out, the Americans we'll iron flat.” The PKI (Indonesian Communist Party) used the same melody and kept the chorus. The song, in other words, still circulates, though I doubt most Muslim Moluccans would be aware of this genealogy. Collins further pointed out that both "team names"_pasukan agas and pasukan linggis_-are entirely Indonesian, not 
being Ambonese Malay or emblematically Ambonese Malay. He also suggested how the different names index the different self-images of the opponents (and thus also, I would add, their intended or imagined effect on the enemy-other). Agas simply cause trouble and misery but do not totally displace the other camp. Linggis, on the other hand, implies the entire removal and dislocation of the opponent. I thank both Wim Manuhutu and especially Jim Collins for their help in unpacking these terms.

22 Many such poems and letters, as well as drawings, have been collected in publications put out by NGOs or other humanitarian-oriented groups. At least some of the children's work is produced in the context of post-violence trauma therapy and rehabilitation programs carried out by a few such organizations. See, for instance, Kisah di Balik Kehidupan: Anak Pengungsi Maluku Utara di Manado dalam Gambar dan Puisi (Manado: Yayasan Pelita Kasih Abadi/Catholic Relief Services Indonesia, 2001); "Program Therapi Emosional Pengungsi Anak di Manado (Jan-Maret 2001): Hasil Puisi," (Manado: Yayasan Pelita Kasih Abadi/Catholic Relief Services Jakarta), unpublished ms.; "Kumpulan Puisi Sanggar Kreatif Anak Bitung (Sept.-Des. 2000), Rakit Communication, unpublished ms.; Rumah Seng Ada Pintu: Anak-Anak Maluku 'Korban Kerusuhan'/Een Huis Zonder Deur: Molukse Kinderen: "Slachtoffers van Geweld” (Utrecht: Stichting TitanE 2001); and on such projects, "Ambon children express trauma through art," The Jakarta Post, May 10, 2002. The last begins with a letter from "Sukardi," a refugee in Makassar, to his friend "Tammi Aimi" in Ternate, N. Maluku, in which he expresses longing for his friend, but adds "I'm scared, wondering if you, my friend Tammi, are willing to welcome me back, as we saw our family among those who attacked yours." These trauma and post-violence programs are highly complicated projects resting on specific conceptions of childhood, memory, violence, and the future, and they deserve further, in-depth study. My thanks to Katinka van Heeren for bringing The Jakarta Post article to my attention.

23 This highlighting of children echoes other recent productions-one in which, notably, kids across the nation address letters to God, a symbol of order in a world where not only government and politics but, again, adults seem to fail them. The ninety-minute film, Viva Indonesia, produced by Garin Nugroho and the SET Foundation in 2001, features five short stories by four different directors. Visi Anak Bangsa and Anak Seribu Pulau: Kisah Anak-Anak Indonesia are also relevent. On the latter, see Karen Strassler's "Stories of Culture: Difference, Nation and Childhood," in "Children of a Thousand Islands, An Indonesian Television Series." The online reference is $<$ http://cc.joensuu.fi/sights/karens. htm $>$.

24 Rudi Fofid and Zairin Salempessy, Letter to AJI's (Aliansi Jurnalis Independen) head office about "Journalists in the Disturbances of Ambon" (Wartawan dalam Huru-hara Ambon), February 10, 1999, with thanks to Rudi Fofid. 
25 My discussion here is indebted to Susan Stewart's on multum in parvo or "miniaturized language" in On Longing: Narratives of the Miniature, the Gigantic, the Souvenir, the Collection (Baltimore: Johns Hopkins University Press, 1984), especially pp.52-53.

26 Benedict Anderson, Imagined Communities: Reflections on the Origin and Spread of Nationalism (London: Verso 1991 [1983]), pp.187-88.

27 See James T. Siegel's excellent discussion of how "Indonesian violence often stimulates a recourse to recognition outside the framework of the initial conflict," which he links to the more general lack of sedimented identities or their formulation in a narrow, dialectical sense. See James T. Siegel, The Rope of God, 2nd ed. (Ann Arbor: University of Michigan, 2000 [1969]), p.347-348.

28 More generally, the sense of audience is crucial to the production of political violence; as Ariel Heryanto, writing of the rapes of Chinese-Indonesian women in May of 1998, observes, "political rapes, like all political violence, are statement making. They involve some sort of authorship, medium, message, genre, style, and intended audience. The raped bodies are a sort of medium-comparable to walls vandalized with graffiti-on which the perpetrators inscribe messages directed towards an audience larger than those females directly assaulted. See Ariel Heryanto, "Race, Rape, and Reporting," in Reformasi: Crisis and Change in Indonesia, ed. Arief Budiman, Barbara Hatley, and Damien Kingsbury (Clayton, Australia: Monash Asia Institute 1999), pp.299-334.

29 Such amplification can, incidentally, be quite literal, as on a mural featured in one of many Muslim-produced VCDs (video CDs) showing Jesus holding a globe and the camera zooming in on Israel blown up to continental size, in Konflik Berdarah Maluku. The term "amplification" comes from Marshall Sahlins, who uses it to speak of similar processes in the context of the Peloponnesian Wars (personal communication).

30 For a facsimile and discussion of the letter, see Nanere, Halmahera Berdarah, pp.63-80.

31 On the "newspeak" of reformasi in Indonesia with a special entry on "provokator," see Dirk Vlasblom's "Vademecum van de 'reformasi' in Indonesië. Megafoons en gefluister," NRC Handelsblad, March 4, 2000, p.33

32 See my "Media and Violence in an Age of Transparency: Journalistic Writing on War-Torn Maluku," in Media, Religion, and the Public Sphere, ed. Birgit Meyer and Annelies Moors (in progress).

33 If, as Henk Schulte Nordholt argues, violence has a history in Indonesia, so do its representations of violence (as is true elsewhere). One can speculate, for instance, that the cinematic preservation of mass as opposed to small-scale scenes of violence may lend credence to a communalist reading of the conflict. See Henk 
Schulte Nordholt's nuanced discussion in "A Genealogy of Violence in Indonesia," pamphlet (Lisbon: Centro Portugues de Estudos do Sudeste Asiatico [CEPESA], 2001).

34 With thanks to Farish Noor.

35 Raymond Williams, Marxism and Literature (New York: Oxford University Press, 1977), pp.132-134. See also Arjun Appadurai, Modernity at Large, on what he calls "communities of sentiment" and on mass-mediated sodalities of worship and charisma, pp.8-9, and p.153 on "structures of feeling" in ethnic violence; see also Deborah Poole's excellent discussion of the formation of transnational bourgeois sensibilities through the circulation of late nineteenth-century cartes de visite in Poole, Vision, Race, and Modernity: A Visual Economy of the Andean Image World (Princeton, NJ: Princeton University, 1997), pp.107-141, especially 112-113.

36 The VCD is produced by the Dompet Sosial Ummul Quro based in Bandung. The organization's address, phone and fax numbers, and bank account information are all listed on the VCD jacket. It has a copyright from 2000.

37 I would like to thank Webb Keane for providing me with this term.

38 This kind of suspicion is common among intimate enemies, such as those involved in Ambon's civil war. Appadurai links the extreme violence often characteristic of such conflict to the sense of betrayal between appearance and reality as "a perceived violation of the sense of knowing who the Other was and of rage about who they really turn out to be." Appadurai Modernity at Large, pp.154-55.

39 For another example of the intimate coupling of pockets and identity, see Patricia Spyer, "What's in a pocket? Religion and the Formation of a Pagan Elsewhere in Aru, Eastern Indonesia," in De bindkracht der dingen, Tijdschrift voor Empirische Filosofie, ed. Hans Harbers and Sjaak Koenis, 1, XXIII (1999): 37-49; see also Patricia Spyer, The Memory of Trade: Modernity's Entanglements on an Eastern Indonesian Island (Durham, NC: Duke University Press, 2000), pp.92-100. 
